\title{
Role of Educational Mediain Promoting the Values of Citizenship Among Students of Secondary Schoolsin Zarqa Education Directorate II from View point of Their Teachers
}

\author{
KhitamN. Radwan', Mohammad S. Al-Zboon ${ }^{2} \&$ Malik S. AlZboon ${ }^{3}$ \\ ${ }^{1}$ Ministry of Education, Jordan \\ ${ }^{2}$ Prof. in Educational Foundations, Faculty of Educational Sciences, University of Jordan, Amman, Jordan \\ ${ }^{3}$ University of Jordan, Amman, Jordan \\ Correspondence: Mohammad S. Al-Zboon, Prof. in Educational Foundations, Faculty of Educational Sciences, \\ University of Jordan, Amman, Jordan. E-mail: m.alzboon@ju.edu.jo
}

Received: December 1, 2017

Accepted: January 28, 2018

Online Published: February 7, 2018

doi:10.5539/mas.v12n3p23

URL: https://doi.org/10.5539/mas.v12n3p23

\begin{abstract}
This study aimed at defining the role of educational media in promoting the values of citizenship among students of secondary schools in Zarqa Education Directorate II from viewpoint of their teachers.

The study used a descriptive approach. A questionnaire was developed, consisting of 30 paragraphs, which evaluated the role of educational media in promoting the values of citizenship among students of secondary schoolsin Zarqa Education Directorate II from viewpoint of their teachers. The validity and reliability of the study's tool have been verified. The sample of the study consisted of the schools' teachers of Zarqa Education Directorate II.They were 250 male and female teachers for the academic year 2016-2017 selected from among the schools of Zarqa Education Directorate II.The results of the study were as follows:

- The role of educational media in promoting the values of citizenship among the students of secondary schools in Zarqa Education Directorate II from the viewpoint of their teachers.

- In favor of females, there were statistically significance differences in the role of educational media in promoting the values of citizenship among the students of secondary schools from the viewpoint of their teachers due to gender variable.

- In favor of females, there were statistically significant differences in promoting of the values of citizenship among students of secondary schools in Zarqa Education Directorate II from the viewpoint of their teachers attributed to specialization variable.

- $\quad$ There were no statistically significant differences due to experience variable.

The study recommended achieving the goal of education through the institutions of the Ministry of Education by educational media, and activating the role of educational media to develop the values of citizenship among the students of secondary schools.
\end{abstract}

Keywords: Educational Media, Citizenship Values, Citizenship, Zarqa Directorate of Education II

\section{Introduction}

Education is the most important community tool for building countries and societies, especially with many developed and rapid technologies, and multiple media that produce information. Any progress in any society is measured by how students are prepared to cope with the rapid changes that have taken place in all areas of life. All this cannot be achieved unless there is educational information capable of bringing them to education based on correct understanding of these changes.

Secondary education is a middle stage between primary and higher education. Students of secondary education are adolescents. In this stage the students will become metaphases psychologically, physically, mentally and socially. They have moved from childhood to youth, and may be at some point confused and imbalanced in addition to physiological and social changes, which require guidance, direction and vision unification, proper preparation of citizenship, walking towards it properly. As well as inherent readiness based on effective school leaders to achieve the educational goals until their readiness for college education is assured (2014). 
Secondary stage shall provide students with moral principles and values of citizenship so that they can be effective citizens in a society characterized by applying democracy by activating the role of educational media in providing useful, correct This is by providing reliable information through the school media represented by the school library, and enabling them to express their criticism and opinions to face the current events, as well as making them know the problems of school and education. The activation of the media role is able to give high school students new thinking styles that have the ability to deal with the requirements of the accelerated era, and improve the quality of their performance through Botebal (2016). The study finds that the diversity of educational and cultural programs will assist them to take note of their cultural and educational reality, because education is the preparation of life, and it aims to develop the citizenship values of these young people who are the foundation of the future and the hope of life. They can be proud of their homeland, and aware of the facts around them. All this will be done through educational process, which is one of the pillars of education and citizenship.

The educational media aims at establishing facts, as well as to create a cultural awakening, and affect the mentality of secondary school students and their levels of thinking. The education media means using the school and community media to strengthen the relations between the school and the educational authorities in order to achieve the values of citizenship. The goals of educational media are varied, such as indicated by Dulaimi (2011), including:

Education: through identifying facts and cultural growth within the scope of education in line with the objectives of the Ministry of Education, and to introduce educational content aimed at developing the values of school and community citizenship among secondary school students.It is a combination of education and information through cooperation, and serve educational planners, teachers, curriculum specialists, educational, administrative and technical affairs. In addition, the educational information provides abundance of data, information and educational news to achieve the concept of educational development, and disperse educational values as citizenship, which to be done in a hidden manner. It also changes the behavior of the secondary school students to positive behavior towards society and education by providing a more aesthetic and more useful way of reforming traditional educational systems, and allowing students to think freely and exchange information at various educational levels and planting educational values. This is especially done with the widespread use of modern technology, disseminating information and knowledge very quickly, and adopting this knowledge resulting in the formation of attitudes and behavior modification among secondary students.

The educational media is one of the most important educational tools and an important tool in developing sustainable education. This tool enables students to learn about the knowledge and culture of the community, develop their deep sense of citizenship responsible. Educational school media are varied, including video, audio, and reading. Among the most prominent of these, as mentioned by Ahmed (2008), are:

- Computer: By employing the Internet to refer to national concepts related to citizenship, promote self-learning, and learn how to employ the internet to broaden the horizon and perceptions, create the creative spirit of students, and invest their free time.

- School wall magazines: it is done within the school, under the responsibility of students as a free purposeful activity within the walls of the school. It contains all that matters the students. It can be expressed by symbols and drawings in a manner attracting students and interesting to them.

- School Radio: Prepared by students and supervised by teachers. Under the instructions of the Ministry of Education, the school radio begins with Royal National Anthem, then Surah Al-Fatiha (Holy Quran), and then indicating an article of the Jordanian constitution. It also includes programs of reinforcing the citizenship values of students of different stages that can build up their listening skill.

- School library: It is the most media places in the school through promoting curriculum and has the largest role in changing the behavior of students to positive.

- School exhibitions: shows the student productions of citizenship values, through national celebrations that emphasize these values.

- $\quad$ Field visits, seminars and lectures: organized by the Ministry of Education to the most known areas with a history, as well as receiving well-experienced lecturers who are known in their work to disseminate the citizenship values. These seminars are usually held in a wide place as school's theater by which the students can express their opinions freely and confidently.

Hence, the study concludes that the various media have the greatest role in promoting the values of citizenship among high school students especially since these means are available to all within the tasks assigned to the 
educational process. It also plays a clear and active role in serving educational institutions for deepening the concept of school and values. It has various functions that serve secondary students in particular, including:

Educational Function: Promote education by collecting and classifying information to ensure that secondary school students are upscale. The role of the community education is to clarify the social role of the students and their cultural characteristics, and to invite them to adhere to the values of community citizenship in order to achieve the concept of social control and trust among the individuals themselves, besides the cultural function. The educational media will preserve the cultural identity of the society by inheriting the desired qualities such as justice, equality, cooperation, patriotism, and pride in its heritage. With the tension of life, the divergence of interests, and the existence of repressed conflicts in individuals, the recreational function of any individual will come up as a function of educational information. Devani (2008).

The study finds that through these functions coordination and cooperation between educational institutions such as school can be done, to achieve the goals of education, and to ensure that values of citizenship are taught to high school students in words and behavior. The school is one of the educational institutions,which aims to spread the values of citizenship among high school students in terms of respect, consideration of individual differences, encouraging cooperative work, training students to dialogue and discussion, and teaching them national affiliation by encouraging them to respect the values of citizenship.

The sources of citizenship values are the same of that Islamic legislation: Holy Quran as a book of heaven revealed on Prophet Muhammad (peace be upon him); a holistic approach to all aspects of life, as includes many verses and each verse contained positive or negative values. The second source: the Prophet's Sunnah is all that is narrated from the Prophet Muhammad (peace be upon him) in terms of saying, doing, deciding, or an attribute that is congenital. The third source is consensus, which means determination and perfection. The measurement as the fourth source of the values of citizenship is a measure of something mentioned in the Holy Quran or Sunnah. Ghamdi (2015)

The values of citizenship are clarified when the school curriculum is consistent with the applied reality in representing the sources of the values of citizenship through the role of the teacher and its relationship with secondary students. This relationship is based on mutual trust, respect for others, justice and equality. The secondary stage teacher plays a major role in representing high school students in the values of citizenship, implanting the spirit of belonging to their homeland, and cooperating with parents in emphasizing these values. The impact of these values on individual level is reflected in the formation of high school students, At social level, the values of citizenship serve to consolidate society, bring people together, and safeguard the security and stability of society.

The study finds that through dissemination of citizenship values among secondary students, it has the greatest impact in deepening loyalty and belonging to the homeland and school, despite the differences of religion, culture and ethnicity, all melted into the crucible of one nation. The awareness of citizens in general, and secondary students in particular, of the current events concerning their country, their attention to problems facing the country, and respect for political power, he should be able to self-control, giving priority to national interest over his one, show feelings of tolerance with others anywhere, or anytime, inside or outside the country, with members of the homeland or with expatriates considering them as citizens, and show his behavior and ethics towards his homeland.This will be considered the real citizenship of the secondary student.

Citizenship has many dimensions, including:

- Political:feeling of individual of loyalty and belonging to homeland.

- Cultural: preserving the national identity through what are provided by the country to citizens.

- Economic: as providing basics of life for citizens.

- Cognitive: preserving national identity that to be supported at Arab and global level.

- Social:to show critical thinking skills, the ability to solve problems, peaceful coexistence with others, accept and work with them.

- Values: represent the principles of freedom, justice, equality and democracy. Sacrament (2010)

- Human: humanization of human, openness to others, acceptance of human brotherhood with them.

- Development: global openness to others and learn and review different cultures.

The study concludes that the secondary school teacher is an example for students in influencing their orientation toward true citizenship and values, developing a sense of allegiance to the country and its property, and avoiding 
the wrong practices towards the country and educational institutions.

The values of citizenship will be grown such as a small child who is brought up in the arms of his parents; covering him with family care. These values will be developed at first through the family, the school, and university. The role of educational institutions is no longer limited to knowledge and science, but it is necessary to develop citizenship values of secondary school students through establishing their behaviors within the school learning environments, by dimensions of entrenchment value of citizenship.

\section{Entrenchment Value of Citizenship Includes}

- Cognitive dimension: identifying the effective citizen, enabling him to live peacefully in society, respecting others, and preserving their rights by not deviating from social controls such as religion, customs, traditions, and prevailing customs.

- Skills dimension: to let secondary school students acquire criticism thinking, problem-solving scientifically, focusing on rationality and logic in saying and doing. Hamid (2010).

Any society is having multinational people, cultures and knowledge. Citizenship is established here in its widest form through peaceful coexistence with others, avoiding conflicts, and all that harms the interest of the country. This is in addition to belonging dimension through national identity, responsibility and national duties, and observance of God Almighty such as justice and equality, whatever non-religious bias, and emphasis on religious values.

It is also possible to employ different teaching strategies by the secondary school teacher in praising these values of citizenship and applying them by all workers in educational institutions as educational forms that have the largest role in achieving citizenship.

At the same time, secondary school students need to understand their rights and duties towards their country and learn the basics of successful dialogue and exchange views.They will be allowed to express their views, participate in decision-making, teach them how to be an example to others, give priority of national interest over theirs, and participate in morning school's radio, national celebrations and events. They are required to preserve school property, which is one of the facilities of the country. This can only be done by qualified teachers who offer them advice and guidance and teach them the citizenshipto the interest of their country and theirs.

The school has been the primary reference in the transfer of knowledge and science through its distinguished well-experienced teachers. They have the largest role in the development of citizenship values.At present time, knowledge is varied with resources.In addition, modern technology is used by all educational institutions. The school is no longer solely responsible for the development of the values of citizenship. A meaningful educational media to keep abreast of educational developments and develop the values of citizenship among high school students in preparation for their admission to institutions of higher education has become urgent. Lotfi, Magda (2011).

The teacher in charge is the one who does and develops the students' attitudes toward the true values of citizenship. They teach, spread a culture of peace, cooperate, respect others, work for the country, supervise and guide students to prepare leaders proud of their homeland and cherish it. This can only be done through the development and promotion of democratic values among students. The teacher is the one who faces students daily, both inside and outside the classroom, and deals with them. At this stage, high school students also need autonomy and security. Hence, he must play an active role in promoting the values of citizenship to them to achieve the required level.

Through the work of one of researchers in the Ministry of Education, he noted that the educational media does not play its practical role in promoting the values of citizenship among high school students. The role of educational media in certain situations, such as announcement of secondary school's result, negatively affected the and reduced the attitudes of secondary school students towards the values of citizenship, and increased student orientation at this critical stage of education towards the deviant values, as a result of cultural openness, and lack of awareness of the values of citizenship, making them do not pay attention to these values.

The importance of the study has been defined as discussed above, which presents the role of educational media in promoting the values of citizenship among high school students in Zarqa Education Directorate II from the viewpoint of their teachers.

\section{Problem of the Study}

The problem of the study is to answer the following question: What is the role of educational media in promoting the values of citizenship among high school students from the viewpoint of their teachers? 


\section{Objective and Questions of the Study}

The study aimed to identify the role of educational media in promoting the values of citizenship among high school students from the viewpoint of their teachers.

To achieve this goal, the study's following questions were answered:

Q. 1: What is the role of educational media in promoting the values of citizenship among high school students from the viewpoint of their teachers?

Q. 2: Are there statistically significant differences in the role of educational media in promoting the values of citizenship among high school students from the viewpoint of their teachers due to gender variable?

Q. 3: Are there statistically significance differences in the role of educational media in promoting the values of citizenship among high school students from the viewpoint of their teachers due to specialization variable?

Q. 4: Are there statistically significance differences in the role of educational media in promoting the values of citizenship among high school students from the viewpoint of their teachers due to experience variable?

\section{Importance of Study}

It is hoped that the following entities will benefit from the results of this study:

- Educational policy makers by highlighting the activation of the role of educational purposeful media that to be included within the objectives of the Ministry of Education.

- The Ministry of Education through defining the strengths and weaknesses of the role of educational media in educational institutions in general, and students in secondary schools in particular.

- Teachers of the Ministry of Education in public schools by focusing on the establishment of community and life communication between educational media and high school students.

\section{Definitions of the Study}

The study definitions are defined as follows:

\section{Educational media:}

In language: know something. Bustani (1988)

Idiomatically: a means to be used to produce news and information. The means that are used within the school and community to inform students about the issues of their community. Dulaimi (2011)

Citizenship: derived from homeland where the individual lives. Bustani (1988)

Idiomatically: A trait acquired by a person that give him the right to participate in parliamentary and municipal elections if meets the requirements and satisfy their multiple needs, enabling them to be loyal for their.

Values of citizenship: standards and provisions extracted from the Islamic religion, aimed at controlling the behavior and thinking between the individual and country in which he grew up that to be translated it into reality in order to reach the formation of a good person and a cohesive society.

Zarqa Education Directorate II: The official authoritythat supervises the secondary government schools in Zarqa Governorate.

\section{Limits of the Study}

Human: Male and female teachers of secondary public schools in Zarqa Education Directorate II.

Venue: Public secondary schools in Zarqa Education Directorate II.

Time: The study was limited to male and female teachers of public secondary schools in Zarqa Education Directorate II for the academic year 2016-2017

\section{Previous Studies}

Reference was made to a number of previous Arab and foreign studies that dealt with the role of educational media in promoting the values of citizenship.

\subsection{ArabicStudies}

A study of (Al-Qasim\&Ashour, 2015) entitled, "The Role of Public Schools' Principals in Irbid Governorate in employing Educational Media to Enhance Students' National Belonging", aimed at identifying the role of public schools' principals in Irbid Governorate in employing educational media to enhance the national belonging of the students. To achieve the objectives of the study, the descriptive approach was used. A questionnaire was 
distributed to a random sample consisted of 697 male and female teachers, and 63 of male and female principals.The results showed that the estimates grade of the sample in employing educational media were medium. There were statistically significance differences of for principals and other differences for the benefit of female principals, and no differences due to qualification and experience variable.

A study of (Gedori, 2014) entitled, "The role of educational media in developing performance of high school students educationally and culturally", aimed at defining the impact of educational media represented by the role of the Syrian Educational Satellite channel in developing students' performance educationally and culturally. The researcher used a questionnaire distributed to 800 students. The results showed that there were no statistically significant differences in the impact of educational media due to gender and specialization variables. The sample members approved to a large extent on the impact of educational media in developing their performance educationally and culturally.

A study of (Mohammed, 2013) entitled, "The status quo of educational media in secondary stage from perspective of teachers and students in Sudan", aimed to identify the status quo of educational media in secondary stage from perspective of teachers and students in Sudan. The descriptive approach was also used. The results showed that educational activities in secondary education in Sudan were weak.

A study of (Sanani, 2012) entitled, "The role of educational media in establishing moral values from viewpoint of secondary school teachers in Medina" aimed at identifying the role of educational media in establishing moral values from viewpoint of secondary school teachers in Medina. The study's sample consisted of 624 teachers.A questionnaire was used.The results showed that there were statistically significant differences due to variable of years of experience, qualification, specialization. The fifth factor (the role of educational media in establishing the value of obedience to ruler ranked first, but forth factor (sincerity at work) ranked second, and (establishing value of patience), ranked third, and the second factor (establishing the value of fulfillment in covenant) ranked fourth, but the first factor (establishing the value of Promotion of Virtue and Prevention of Vice) ranked fifth as to agreement of members of the study.

\subsection{Foreign Studies}

A study made by (Son, 2010) aimed at defining the assessment of citizenship education in secondary education in Britain from the viewpoint of teachers and students.The researcher used a descriptive approach. The first tool was questionnaire, and the second was interview. The results showed that the methods of acquiring citizenship in the students related to their selection of appropriate methods for their evaluation of citizenship.The quality of teacher can define the attitudes of students towards it.

A study by (Ovadia, 2001) aimed at detecting the differences in the degree of citizenship values among secondary school students in the United States of America according to gender, class, and raceconcepts. This was made through the role of media education within the school. The sample consisted of 4969 students, and the results of the study showed that the degree of citizenship values among students ranged between high and medium, and there were no differences depending on gender, class (specialization), or race variables.

A study by (Yates, 2002) examined the goal of revealing the future of media education in developing the values of citizenship in schools from perspective of teachers in the state of Georgia, USA.The sample consisted of 96 male and female teachers; chosen deliberately from 20 schools. The results showed high positive perceptions of the role of media education in developing the values of citizenship.

\subsection{Position of Current Study Among Previous Studies}

The previous Arab and foreign studies were used in terms of theoretical literature, tool used, and how to select the study methodology. This study dealt with the role of educational media in promoting the values of citizenship among high school students, which is not discussed by any other studies within the knowledge of researchers.

\section{Method and Procedures}

The study applied descriptive approach within the following procedures:

\subsection{Study Sample}

The members of the study are all male and female teachers of public secondary schools in Zarqa Education Directorate II for the academic year 2016-2017. They were 250 teachers, selected from secondary public schools located within Zarqa Education Directorate II.This is shown in the following table: 
Table 1. Distribution of study members by gender, specialization and experience

\begin{tabular}{llllll}
\hline Gender & Specialization & Humanity & \multicolumn{3}{c}{ Scientific } \\
\hline Gender & Experience & Frequency & Ratio \% & Frequency & Ratio \% \\
\hline \multirow{2}{*}{ Males } & From 1 to 5 & 7 & $2.8 \%$ & 14 & $5.6 \%$ \\
100 & From 6 to 10 & 16 & $6.4 \%$ & 32 & $12.8 \%$ \\
& More than 1 1 & 13 & $5.2 \%$ & 18 & $7.2 \%$ \\
Females & From 1 to 5 & 23 & $9.2 \%$ & 18 & $7.2 \%$ \\
150 & From 6 to 10 & 30 & $12.0 \%$ & 57 & $22.8 \%$ \\
Total & More than 1 1 & 10 & $4.0 \%$ & 12 & $4.8 \%$ \\
\hline
\end{tabular}

\subsection{Tool Stability}

To verify the stability of the questionnaire, the internal consistency coefficient (Alpha-Kronbach)was found, and the stability coefficient was 0.94 .

\subsection{Tool Validity}

The questionnaire was presented to ten arbitrators in the field of jurisdiction, to ensure the tool in terms of construction, and language integrity and clarity.The observations of all arbitrators were taken.

\subsection{Tool Variables}

The study included the following variables:

Independent variable: the role of educational media.

Dependent variable: the degree of response of male and female teachers.

Medium variable: It has three levels

Gender: male and female.

Specialization, and experience

\subsection{Statistical Processing Methods}

To realize the goals of study, the Statistical Package for Social Sciences (SPSS) was used to analyze the data and obtain the results as follows:

- Frequencies and percentages to describe characteristics of the study members.

- Arithmetical averages and standard deviations to identify responses of the sample members on each of section of questionnaire.

- Cronbach's Alpha coefficient to verify the stability of the questionnaire.

- T-test for independent samples to define the significance of differences between two independent groups.

- One-way ANOVA analysis to define significance of differences between more than two independent groups.

\section{Study Results}

The results of the study are presented below:

10.1 Results Relevant to Question (1): What is the Role of Educational Media in Promoting the Values of Citizenship among High School Students from Viewpoint of Their Teachers?

This question was answered by calculating the arithmetical averages, the standard deviations and the order of the teachers' approval grades on the role of the educational media in promoting the values of citizenship among secondary students. The results are defined in the following table 
Table 2. Arithmetical averages, standard deviations and order of response grades of members on paragraphs relating to the role of educational media in promoting the values of citizenship among secondary school students in descending order, according to arithmetical average

\begin{tabular}{|c|c|c|c|c|c|}
\hline No. & Paragraph & $\begin{array}{l}\text { Arithmetical } \\
\text { Average }\end{array}$ & $\begin{array}{l}\text { standard } \\
\text { deviation }\end{array}$ & $\begin{array}{l}\text { Approval } \\
\text { Degree }\end{array}$ & Order \\
\hline 5 & $\begin{array}{l}\text { Inviting always to student dialogues that } \\
\text { support the values of citizenship }\end{array}$ & 3.39 & 1.171 & Medium & 1 \\
\hline 18 & Clarifying historical facts & 3.36 & 1.137 & Medium & 2 \\
\hline 19 & $\begin{array}{l}\text { Highlight the importance of the school role in } \\
\text { promoting citizenship values }\end{array}$ & 3.26 & 1.104 & Medium & 3 \\
\hline 3 & Encourage participation in national events & 3.24 & 1.127 & Medium & 4 \\
\hline 2 & Promoting national belonging & 3.22 & 1.073 & Medium & 5 \\
\hline 28 & $\begin{array}{l}\text { Take advantage of technology in promoting } \\
\text { citizenship values }\end{array}$ & 3.22 & 1.193 & Medium & 5 \\
\hline 13 & Emphasis on national behavior & 3.21 & 1.133 & Medium & 7 \\
\hline 11 & $\begin{array}{l}\text { Linking the school curriculum to citizenship } \\
\text { values }\end{array}$ & 3.20 & 1.190 & Medium & 8 \\
\hline 10 & Encourage national initiatives & 3.19 & 1.124 & Medium & 9 \\
\hline 12 & Promoting social justice & 3.17 & 1.168 & Medium & 10 \\
\hline 7 & Emphasis on respecting VIPs of country & 3.16 & 1.154 & Medium & 11 \\
\hline 17 & $\begin{array}{l}\text { Taking care of student activities that reinforce } \\
\text { the values of citizenship }\end{array}$ & 3.16 & 1.123 & Medium & 11 \\
\hline 25 & Directing instructions and systems. & 3.16 & 1.211 & Medium & 11 \\
\hline 6 & $\begin{array}{l}\text { Encourage students to engage in volunteer } \\
\text { work within the school }\end{array}$ & 3.14 & 1.094 & Medium & 14 \\
\hline 23 & Highlighting on educational problems & $3: 14$ & 1.203 & Medium & 14 \\
\hline 24 & Strengthen loyalty to leadership & 3.14 & 1.181 & Medium & 14 \\
\hline 27 & Establishing national historical values & 3.14 & 1.174 & Medium & 14 \\
\hline 9 & $\begin{array}{l}\text { Calling for peaceful coexistence with other, } \\
\text { especially that number of expatriates is } \\
\text { increased }\end{array}$ & 3.13 & 1.156 & Medium & 18 \\
\hline 4 & Warning of deviant values & 3.12 & 1.137 & Medium & 19 \\
\hline 20 & $\begin{array}{l}\text { Call for making school exhibitions that } \\
\text { develop the values of citizenship }\end{array}$ & 3.12 & 1.188 & Medium & 19 \\
\hline 8 & Clarify qualities of effective citizen & 3.05 & 1.141 & Medium & 21 \\
\hline 21 & Rooting of national identity & 3.05 & 1.265 & Medium & 21 \\
\hline 26 & Remind students of national heritage & 3.03 & 1.158 & Medium & 23 \\
\hline 15 & $\begin{array}{l}\text { Introducing non-class programs that promote } \\
\text { citizenship values }\end{array}$ & 3.02 & 1.212 & Medium & 24 \\
\hline 16 & Link school to community events & 2.98 & 1.185 & Medium & 25 \\
\hline 14 & Ensure students to maintain public property & 2.96 & 1.200 & Medium & 26 \\
\hline 29 & Praise the educational role of the school & 2.96 & 1.233 & Medium & 26 \\
\hline 22 & Modifying student behavior & 2.93 & 1.233 & Medium & 28 \\
\hline 1 & $\begin{array}{l}\text { Encourage students to abide by national } \\
\text { obligations }\end{array}$ & 2.92 & 1.228 & Medium & 29 \\
\hline 30 & $\begin{array}{l}\text { Guiding and advising parents on how to deal } \\
\text { with developmental characteristics of their } \\
\text { children }\end{array}$ & 2.91 & 1.265 & Medium & 30 \\
\hline \multicolumn{2}{|r|}{ General average } & 3.12 & 0.714 & Medium & \\
\hline
\end{tabular}

The results of the arithmetical averages of paragraphs concerning the role of educational media in promoting the values of citizenship among high school students ranged between (2.91-3.39); all with medium approval. Paragraph 5 (Inviting always to student dialogues that support the values of citizenship) scored the highest arithmetical average by (3.39), while paragraph (30) (Guiding and advising parents on how to deal with developmental characteristics of their children) scored the lowest average by (2.91). The total number of paragraphs obtained an average of (3.12) with medium degree of approval. The following scale was used to 
indicate the average responses of the sample to the degree of approval.

\begin{tabular}{cl}
\hline Arithmetical Average & Degree of approval \\
\hline 4.2 and more & Very High \\
From 3.4 to less than 4.2 & High \\
From 2.6 to less than 3.4 & Medium \\
From 1.8 to less than 2.6 & Weak \\
Less than 1.8 & Very Weak \\
\hline
\end{tabular}

10.2 Results Related to the Question (2): Are There Statistically Significant Differences in the Role of Educational Media in Promoting the Values of Citizenship among High School Students from the Viewpoint of Their Teachers Due to Gender Variable?

This question was answered by calculating the arithmetical averages and standard deviations of teachers' approval grades for the role of educational media in promoting the values of citizenship among secondary students due to gender variable, and using the T-test to define the significance of differences between these averages, as shown in the following table:

Table 3. Results of "T-Test" for independent samples to define The significance of differences in arithmetical averages of responses degrees of study members to educational role of media in promoting values of citizenship among secondary school studentsdue to gender variable

\begin{tabular}{lllllll}
\hline Gender & No. & Arithmetical Average & Standard deviation & "T" Value & $\begin{array}{l}\text { Freedom } \\
\text { Degrees }\end{array}$ & Significance Level \\
\hline Males & 100 & 2.93 & 0.576 & -3.512 & 248 & 0.001 \\
Females & 150 & 3.25 & 0.768 & & & \\
\hline
\end{tabular}

The results showed that there were statistically significant differences in the role of educational media in promoting the values of citizenship among high school students from viewpoint of their teachers due to gender variable. The arithmetic mean show these differences in favor of females.

10.3 Results Related to Question (3): Are There Statistically Significant Differences in the Role of Educational Media in Promoting the Values of Citizenship among High School Students from the Viewpoint of Their Teachers Due to Specialization Variable?

This question was answered by calculating the arithmetical average and standard deviations of teachers' approval degrees for the role of educational media in promoting the values of citizenship among secondary students due to specialization variable, and using $\mathrm{T}$-test to define the significance of differences between these averages. The results are shown in the following table.

Table 4. Test "T" for independent samples to find the significance of differences in arithmetic averages scores results Approval of teachers in the educational role of the media in promoting the values of citizenship among secondary school students according to specialization variable

\begin{tabular}{lllllll}
\hline Gender & No. & $\begin{array}{l}\text { Arithmetical } \\
\text { Average }\end{array}$ & $\begin{array}{l}\text { Standard } \\
\text { deviation }\end{array}$ & $\begin{array}{l}\text { "T" } \\
\text { Value }\end{array}$ & $\begin{array}{l}\text { Freedom } \\
\text { Degrees }\end{array}$ & $\begin{array}{l}\text { Significance } \\
\text { Level }\end{array}$ \\
\hline $\begin{array}{l}\text { Human } \\
\text { sciences }\end{array}$ & 151 & 3.22 & 0.579 & 2.622 & 248 & 0.009 \\
Scientific & 99 & 2.98 & 0.864 & & & \\
\hline
\end{tabular}

The results showed significant differences in the degree of teachers' approval of the role of educational media in promoting the values of citizenship among high school students due to specialization variable.

10.4 Results Related to Question (4): Are there Statistically Significant Differences in the Role of Educational Media in Promoting the Values of Citizenship Among High School Students from Viewpoint of their Teachers due Experience Variable?

This question was answered by calculating the arithmetical averages and standard deviations of the role of educational media in promoting the values of citizenship among high school students from viewpoint of their 
teachers according to experience variable. The results are as shown in the following table.

Table 5. Mathematical averages and standard deviations of teachers' approval grades on the role of educational media in promoting the values of citizenship among secondary school students depending on experience variable

\begin{tabular}{cccc}
\hline Years of Experience & No. & Arithmetical Average & Standard Deviation \\
\hline From 1 - 5 & 62 & 3.14 & 0.966 \\
From 6-10 & 135 & 3.17 & 0.316 \\
More than 11 & 53 & 2.98 & 1.029 \\
\hline
\end{tabular}

In order to determine the significance of these differences, ANOVA test was used. The results are as shown in the following table.

Table 6. Analysis of variance test to determine significance of differences in degrees of teachers' approval on the role of educational media in promoting the values of citizenship among secondary school students depending on experience variable

\begin{tabular}{llllll}
\hline Variance Source & Total squares & $\begin{array}{l}\text { Freedom } \\
\text { Degrees }\end{array}$ & $\begin{array}{l}\text { Squares } \\
\text { Average }\end{array}$ & "P" Value & Level of significance \\
\hline Between groups & 1.442 & 2 & 0.721 & 1.420 & 0.244 \\
Within groups & 125.344 & 247 & 0.507 & & \\
Total & $\mathbf{1 2 6 . 7 8 5}$ & $\mathbf{2 4 9}$ & & & \\
\hline
\end{tabular}

The results showed that there are no statistically significant differences in the role of educational media in promoting the values of citizenship among high school students due to experience variable between male and female teachers regardless of their different experiences.

\section{Results Discussion}

11.1 Discussion of the Results Related to Question (1): What is the Role of Educational Media in Promoting the Values of Citizenship Among High School Students from Viewpoint of their Teachers?

The results of the arithmetical averages of paragraphs concerning the role of educational media in promoting the values of citizenship among high school students ranged between (2.91-3.39); all with medium approval. Paragraph 5 (Inviting always to student dialogues that support the values of citizenship) scored the highest arithmetical average by (3.39), while paragraph (30) (Guiding and advising parents on how to deal with developmental characteristics of their children) scored the lowest average by (2.91). The total number of paragraphs obtained an average of (3.12) with medium degree of approval.

This result attributed to that the goal of any educational institution is to increase the culture of dialogue through educational media, due to its positive impact on the personality of secondary school students, and increase the values of their citizenship. These dialogues are based on fundamental and strong pillars such as constructive criticism and participation in decision-making. These dialogues reduce conflicts between different students, such as discrimination. Instead, it provides a mutual respect, self-confidence and positive communication between them and officials and corrects their mistakes. These dialogues aimed to strengthen the values of citizenship, create a conscious aware generation that can fight subversive ideas to realize progress and development.

11.2 Discussion of the Results Related to Question (2): Are there Statistically Significant Differences in the Role of Educational Media in Promoting the Values of Citizenship Among High School Students from Viewpoint of their Teachers Due to Gender Variable?

The results of statistical averages and standard deviations showed statistically significant differences in the role of educational media in promoting the values of citizenship among secondary school students from viewpoint of their teachers due to gender variable.Arithmeticalaverages showed that these differences were in favor of females. The study attributed this result to the fact that female teachers are more likely to carry the profession of education than male teachers, and that the abundance of passion makes them more committed to teaching the values of citizenship among high secondary students and that they practice it more effectively and with a higher sense of citizenship. Emphasis on promoting civic values in the school day in practical behaviors, illustrated by participation in national events and celebrations, and participation in civil society institutions. 
11.3 Discussion of the Results Related to Question (3): Are there Statistically Significant Differences in the Role of Educational Media in Promoting the Values of Citizenship Among High School Students from Viewpoint of their Teachers Due to Specialization Variable?

The results showed that there were statistically significant differences in degree of teachers' approval on the role of educational media in promoting the values of citizenship among high school students due to specialization variable.The arithmetical average show that these differences were in favor of humanity specializations. This result is come as humanity specializations focus on values of citizenship; the nature of school curriculum imposes these citizenship values, as well as those most scientific disciplinesof practical and mathematical applications and chemical reactions are far from linking the school curriculum with reality and values of citizenship.

11.4 Discussion of the Results Related to Question (4): Are there Statistically Significant Differences in the Role of Educational Media in Promoting the Values of Citizenship Among High School Students from Viewpoint of their Teachers due to Experience Variable?

The results showed that there are no statistically significant differences in the role of educational media in promoting the values of citizenship among high school students due to experience variable between male and female teachers regardless of their different experiences. This result is attributed to the routine of educational institutions with regard to expertise in scientific disciplines and humanities, similarity of male and female schools in terms of daily school routines. They have no desire to renew, or participate in promoting the citizenship values of secondary school students.

\section{Recommendations}

Based on the findings above, the study recommends the following:

- Realizing the goal of education through the institutions of the Ministry of Education by educational media.

- Activating the role of educational media to develop the values of citizenship among high school students.

- Making studies similar to this study with respect to students of higher education institutions to continue developing the role of educational media in promoting the values of citizenship among postgraduate students.

\section{References}

Ahmed, A. (2008). Educational Media and its Role in Education. Amman: Dar Kunouz Al-Marifa.

Azmi, Mezna, Rumeidi, \& Khaled (2011). The Role of Teachers in Developing Citizenship Values among High School Students in Kuwait. Journal of Education at Kuwait University, 99(25), c2, 175-205.

$\mathrm{Bu}, \mathrm{T}$., Saad, E., Yahi, \& Samia (2016). The role of the school in developing the values of citizenship among learners: Middle and secondary education stage as a model. Human and Social Sciences Journal, University of QasidiMarbah, Wargla, Algeria, 32(2), 91-103.

Bustani, P. (1988). Muheet Al-Muheet. Lebanon: Library of Lebanon.

Devani, A. (2008). Educational Media, Concept, Areas, Activities and Arts. Alexandria: Dar Al Wafaa.

Dulaimi, A. R. (2011). Educational Media. Amman: Dar Al-Masira.

Ghamdi, A. (2015). The Role of Teacher of Islamic Education in Promoting Values of Citizenship among High School Students in Taif. Journal of Education, Azhar University: Egypt, 2(165), 783-812.

Gidori, S. (2014). The role of Educational Media in Developing the Performance of High School Students in Education \& Culture. Al-Quds Open University Journal for Research and Studies, Palestine, (34), 399-427.

Hameed, J., \& Ben, M. (2010). The Role of Education in Establishing the Concept of Citizenship. Jouba Magazine, Saudi Arabia, Abdul Rahman Al-Sudairy Foundation, (26), 130-166.

Lotfi, M. (2011). Educational Information Technologies. Amman: Dar Osama.

Mohammad, Q., \& Mohammad, A. (2016). The Role of Principals of Public Schools in Governorate of Irbid in Employing Educational Media to Enhance Citizenship Belonging of Students. Al-Quds Open University Journal for Educational and Psychological Studies, Palestine, 4(15), 389-429.

Mohammed, A. (2013). Status Quo of Educational Media in Secondary Stage from Perspective of Teachers and Students in Sudan. Jerash Journal for Research and Studies, 15(Special Issue), 91-105.

Mohammed, S. (2010). Education and Culture of Citizenship Development. Journal of the Association of Modern Education, 3(8). 
Ovadia, S. (2001). Race, Class and Gender Differences in High school Seniors, Values: Applying Interaction Theory in Empirical Analysis. Social Science Quarterly, 82(1), 340-356.

Sanani, A. M. (2012). The Role of Educational Media in Establishing Moral Values from Viewpoint of Secondary School Teachers in Medina. Unpublished Master Thesis, Saudi Arabia: Islamic University of Medina.

Son, R. (2010). Citizenship In Secondary Education In England. Research Paper In Education. Journal of Philosophy of Education, 25(4), 457-478.

WaladGweel, K. (2014). Secondary Role in Socialization of Adolescent Student. Social Studies - Al-Basira Center for Research. Consultancy and Educational Services - Algeria, 16(2), 9-22.

Yates, B. (2002). Media Education's Present and Future: A Survey of Teachers. Studies in Media \& Information Literacy Education, 2(3), 1-3.

\section{Copyrights}

Copyright for this article is retained by the author(s), with first publication rights granted to the journal.

This is an open-access article distributed under the terms and conditions of the Creative Commons Attribution license (http://creativecommons.org/licenses/by/4.0/). 